\title{
A case of bismuth intoxication with irreversible renal damage
}

This article was published in the following Dove Press journal: International Journal of Nephrology and Renovascular Disease 6 November 2013

Number of times this article has been viewed

\section{Abdulsamet Erden \\ Samet Karahan \\ Kadir Bulut \\ Mustafa Basak \\ Tuncay Aslan \\ Ali Cetinkaya \\ Hatice Karagoz \\ Deniz Avci}

Internal Medicine Department, Kayseri Training and Research Hospital, Kayseri, Turkey
Correspondence: Samet Karahan Internal Medicine Department, Kayseri Training and Research Hospital, Kayseri Eğitim Araștırma Hastanesi, iç Hastalıkları Kliniği, 9. Blok 3. Kat Kocasinan, Kayseri, Turkey Tel +90 5063020036

Email doktorsamet@yahoo.com
Abstract: Bismuth is a chemical element symbolized as Bi and is a trivalent poor metal, which chemically resembles arsenic and antimony. Colloidal bismuth subcitrate (CBS) and bismuth subsalicylate are the bismuth salts widely used in the treatment of peptic ulcers, functional dyspepsia, and chronic gastritis. Intoxications with CBS are rare. In a few case reports, acute renal failure was described, but the literature review revealed no chronic renal failure related to CBS intoxication. In this case report we present a 21-year old female with chronic renal failure after a one year follow-up of CBS intoxication.

Keywords: acute renal failure, bismuth, intoxication, chronic renal failure

\section{Introduction}

Bismuth is a chemical element with the symbol Bi and atomic number 83 . Bismuth, a trivalent poor metal, chemically resembles arsenic and antimony. Bismuth salts, especially colloidal bismuth subcitrate (CBS) and bismuth subsalicylate, are widely used to treat peptic ulcers, functional dyspepsia, and chronic gastritis. ${ }^{1,2}$ Other names for CBS include colloidal bismuth subcitrate and tripotassium dicitratobismuthate.

In general, the mechanisms of action of CBS are still not fully understood, although prostaglandin $\mathrm{E}_{2}$-mediated mechanisms, antimicrobial activity, and alteration of the viscosity of the gastric mucus with decreased $\mathrm{H}^{+}$diffusion are discussed. ${ }^{2}$ Intoxications with $\mathrm{CBS}$ are rare. In a few case reports, acute renal failure was described. ${ }^{3}$

The reported toxic effects caused by overdose of bismuth compounds include encephalopathy, nephropathy, osteoarthropathy, gingivostomatitis, and colitis. ${ }^{3}$ Bismuth poisoning mostly affects the kidney, liver, and bladder. Chronic exposure to high levels of bismuth salts result in encephalopathy, whereas acute toxicity manifests as nephrotoxicity. ${ }^{2}$ In this case report, we present a 21 -year-old woman with chronic renal failure 1 year after CBS intoxication.

\section{Case report}

A 21-year-old woman was admitted to the emergency department 4 hours after taking 20 tablets of CBS in a suicide attempt. Each tablet included $300 \mathrm{mg}$ of CBS, which is equivalent to $120 \mathrm{mg}$ of $\mathrm{Bi}_{2} \mathrm{O}_{3}$. There was no alcohol or another intravenous drug usage. In the emergency service, the patient underwent gastric lavage and received intravenous fluid therapy, after which she was admitted to the internal medicine intensive care unit. 
Physical examination upon admission was unremarkable: blood pressure, 100/60 mm Hg; pulse, 76 beats/minute; respiration rate, 12 breaths/minute; and body temperature, $36.5^{\circ} \mathrm{C}$. Laboratory tests were as follows: white blood cell count, $7860 / \mathrm{mm}^{3}$; hemoglobin, $10.8 \mathrm{~g} / \mathrm{dL}$; platelet count, $445,000 / \mathrm{mm}^{3}$; serum sodium, $141 \mathrm{mEq} / \mathrm{L}$; potassium, $4.3 \mathrm{mEq} / \mathrm{L}$; chloride, $104 \mathrm{mEq} / \mathrm{L}$; glucose, $108 \mathrm{mg} / \mathrm{dL}$; amylase, $85 \mathrm{U} / \mathrm{L}$; aspartate aminotransferase (AST), $35 \mathrm{U} / \mathrm{L}$; alanine aminotransferase (ALT), $14 \mathrm{U} / \mathrm{L}$; lactate dehydrogenase (LDH), $150 \mathrm{U} / \mathrm{L}$; hepatitis B surface antigen, nonreactive; and anti-hepatitis $\mathrm{C}$ virus, nonreactive. Her INR was reported to be normal at 1.1. Thyroid function tests were normal. Chest radiography also showed no abnormalities. Abdominal ultrasonography demonstrated slightly increased echogenicity in the renal parenchyma. Electrocardiography and echocardiography findings were normal. The patient rapidly became oliguric $(<500 \mathrm{~mL} /$ day $)$ and thereafter was anuric $(0 \mathrm{~mL} /$ day $)$. Blood creatinine increased to $2.6 \mathrm{mg} / \mathrm{dL}$ (blood urine nitrogen $[\mathrm{BUN}], 8 \mathrm{mg} / \mathrm{dL}$ ) during the first 24 hours and to $3.1 \mathrm{mg} / \mathrm{dL}$ (BUN, $11 \mathrm{mg} / \mathrm{dL}$ ) the next day. The baseline creatinine value was normal. Nevertheless, levels of LDH, ALT, and AST were elevated at 1,129 U/L, $62 \mathrm{U} / \mathrm{L}$, and $139 \mathrm{U} / \mathrm{L}$, respectively. Her scleraes were anicteric. The abdomen was soft, flat, and without palpable organomegaly. There was no edema. Arterial blood gases showed metabolic acidosis with a $\mathrm{pH}$ of 7.28, $\mathrm{P}_{\mathrm{a}} \mathrm{CO}_{2}$ of $30 \mathrm{mmHg}, \mathrm{P}_{\mathrm{a}} \mathrm{O}_{2}$ of $80 \mathrm{mmHg}$, BE of $-11 \mathrm{mmol} / \mathrm{L}$, and $\mathrm{HCO}_{3}$ of $14 \mathrm{mmol} / \mathrm{L}$. Blood chemistry and urine sediment showed signs of proximal tubular dysfunction (Fanconi's syndrome) with hypophosphatemia, hypouricemia, metabolic acidosis, and renal glycosuria despite normal plasma glucose concentration.

After consultation with personnel at Turkey's National Poison Information Center, we started oral treatment with the chelating agent sodium-2,3-dimercapto-1-propanesulfonate (DMPS), which is related structurally to 2,3-dimercapto-1propanol (dimercaprol, also known as British anti-Lewisite), using the following regimen: DMPS, $600 \mathrm{mg}$ orally every 8 hours for 14 days. Hemodialysis was performed because of anuria and severe metabolic acidosis. Hemodialysis was conducted daily for the first 4 days and then three times weekly. Arterial blood gases returned to normal. Afterwards, the patient's urine output progressively increased. Levels of LDH, ALT, and AST also returned to normal. The patient recovered clinically and was discharged after 15 days in hospital. Her serum creatinine and BUN levels upon discharge were $5.2 \mathrm{mg} / \mathrm{dL}$ and $20.0 \mathrm{mg} / \mathrm{dL}$, respectively. Eight weeks after discharge, the patient's renal function (serum creatinine and BUN) test results remained high. The patient is still on hemodialysis approximately 1 year later.

\section{Discussion}

We have described the first case of a patient with chronic renal failure after ingestion of CBS in a suicide attempt. We performed gastric lavage and prescribed early hydration. In cases of renal failure, hemodialysis combined with DMPS seems to be useful for bismuth elimination. ${ }^{4}$ Succimer (2,3dimercapto-succinicacid) is an analogue of dimercaprol and has replaced dimercaprol as one of the main antidotes used in the management of poisoning by lead and other heavy metals. ${ }^{5}$ The advantages of succimer are that it is effective by oral administration because of its water-soluble pattern, it is well-tolerated, it has relatively low toxicity, and it can be given at the same time as iron supplements to treat iron deficiency anemia. ${ }^{5}$ However, in vivo studies suggested that DMPS is a more potent chelator of bismuth than succimer. ${ }^{6}$

Less than $1 \%$ of an oral dose of bismuth is absorbed. The remainder is excreted in the feces as insoluble salts and these change the stool color to black. The half-life of bismuth in blood varies from 3.5 minutes to 17-22 years. The liver and kidney have been shown to be the target organs of acute CBS toxicity. The concentration of bismuth in the kidney and its retention time is higher than in other organs (eg, lung, liver, brain). Bismuth binds to a metal binding protein in proximal renal tubule cells and remains bound in this way for months. ${ }^{3}$

In acute bismuth nephrotoxicity, renal blood flow and glomerular filtration rate are both decreased. The damaged tubules in the corticomedullary boundary zone were identified as $\mathrm{S}_{3}$ segments of the proximal tubule in a previous experiment, on the basis of their anatomical location, their characteristic large brush borders, and the absence of Tamm-Horsefall protein. ${ }^{7}$ The necrosis of the epithelial cells of the $\mathrm{S}_{3}$ segment of the proximal tubule occurs as early as 3 hours after CBS administration and is followed by a similar event in the $S_{1} / S_{2}$ segment 3-9 hours later. ${ }^{8}$ Fanconi's syndrome was observed in the current case study. Because of the tubular necrosis of proximal tubule, defective reabsorption occurres. Although reversible Fanconi's syndrome has been described in heavy metal intoxication, ${ }^{9}$ our patient developed irreversible Fanconi's syndrome that resulted in chronic kidney failure. The patient continues to require hemodialysis.

Türkez et $\mathrm{al}^{10}$ provided biochemical evidence of CBSinduced hepatic injury. As a matter of fact, the elevation in 
transaminase is encountered in conditions causing hepatocellular damage, loss of functional integrity of the cell membrane, and necrosis such as in chemically induced liver injury and elevation in enzymes. ${ }^{11}$ Türkez et $\mathrm{al}^{10}$ showed that the lowest doses of CBS caused the greatest increases of ALT and LDH after 24 hours. ALT and LDH were increased in our patient as well. In case reports published thus far, ALT and LDH were normal and no one had chronic renal failure. The increased ALT and LDH in our patient may be a poor prognostic factor.

Clinicians should be aware that chronic renal failure could occur after bismuth intoxication. Therefore patients with bismuth intoxication should be monitored with renal function tests, liver function tests, and monitoring of arterial blood gases.

\section{Disclosure}

The authors report no conflicts of interest in this work.

\section{References}

1. Gorbach SL. Bismuth therapy in gastrointestinal diseases. Gastroenterology. 1990;99(3):863-875.

2. Wagstaff AJ, Benfield P, Monk JP. Colloidal bismuth subcitrate. A review of its pharmacodynamic and pharmacokinetic properties, and its therapeutic use in peptic ulcer disease. Drugs. 1988;36(2):132-157.
3. Cengiz N, Uslu Y, Gök F, Anarat A. Acute renal failure after overdose of colloidal bismuth subcitrate. Pediatr Nephrol. 2005;20(9): $1355-1358$.

4. Stevens PE, Moore DF, House IM, Volans GN, Rainford DJ. Significant elimination of bismuth by haemodialysis with a new heavy-metal chelating agent. Nephrol Dial Transplant. 1995;10(5):696-698.

5. Volans GN, Karalliedde L, Wiseman HM. Review of Succimer for Treatment of Lead Poisoning. Geneva, Switzerland: World Health Organization; 2010. Available from: http://www.who.int/selection_ medicines/committees/expert/18/applications/succimer.pdf. Accessed October 15, 2013.

6. Slikkerveer A, Noach LA, Tytgat GN, Van der Voet GB, De Wolff FA. Comparison of enhanced elimination of bismuth in humans after treatment with meso-2,3-dimercaptosuccinic acid and D,L-2,3dimercaptopropane-1-sulfonic acid. Analyst. 1998;123(1):91-92.

7. Leussink BT, Slikkerveer A, Engelbrecht MRW, et al. Colloidal bismuth subcitrate-induced nephrotoxicity: reversibility and morphology (abstract). Proceedings of the Dutch Society of Nephrology 59th Scientific Meeting; January 17, 1998; Leiden The Netherlands. Kidney Int. 1999;55(3):1170.

8. Leussink BT, Slikkerveer A, Krauwinkel WJ, et al. Bismuth biokinetics and kidney histopathology after bismuth overdose in rats. Arch Toxicol. 2000;74(7):349-355.

9. Loghman-Adham M. Aminoaciduria and glycosuria following severe childhood lead poisoning. Pediatr Nephrol. 1998;12(3): $218-221$.

10. Türkez H, Geyikoğlu F, Keleş MS. Biochemical response to colloidal bismuth subcitrate: dose-time effect. Biol Trace Elem Res. 2005;105(1-3):151-158.

11. Sujatha R, Jayakumar AR, Krishnamoorthy MS, Paul V, Jayakumar R. Behavioural and biochemical changes after simultaneous and posttreatment of vitamin A and D on cadmium toxicity. Environ Toxicol Pharmacol. 1999;7(3):189-197.

\section{Publish your work in this journal}

The International Journal of Nephrology and Renovascular Disease is an international, peer-reviewed open-access journal focusing on the pathophysiology of the kidney and vascular supply. Epidemiology, screening, diagnosis, and treatment interventions are covered as well as basic science, biochemical and immunological studies. The journal welcomes

\section{Dovepress}

original research, clinical studies, reviews \& evaluations, expert opinion and commentary, case reports and extended reports. The manuscript management system is completely online and includes a very quick and fair peerreview system, which is all easy to use. Visit http://www.dovepress.com/ testimonials.php to read real quotes from published authors. 